\title{
THE STUDENTS' MATHEMATICAL CREATIVE THINKING ABILITY OF JUNIOR HIGH SCHOOL THROUGH PROBLEM-SOLVING APPROACH
}

\author{
Heris Hendriana*1 ${ }^{1}$ Fika Muji Fadhilah ${ }^{2}$ \\ ${ }^{1}$ Institut Keguruan dan Ilmu Pendidikan Siliwangi \\ ${ }^{2}$ SMP Negeri 2 Cilamaya Kulon Karawang
}

\section{Article Info \\ Article history: \\ Received Aug 30, 2018 \\ Revised Sep15, 2018 \\ Accepted Jan 12, 2019}

\section{Keywords:}

Problem-Solving Approach Creative Thinking

\begin{abstract}
This study aims to examine the achievement and improvement of mathematical creative thinking skills of students whose learning uses a problem-solving approach compared to those using ordinary learning and the implementation of learning steps using a problem-solving approach in the field. The method used in this study is a quasi-experimental method, because there is manipulation of treatment, where the experimental class uses learning with a problem-solving approach, and the control class uses ordinary learning. The population in this study were all seventh-grade students of SMP Negeri 1 Cilamaya Wetan. With the subject of the sample are two classes VII, while the sample was chosen 2 classes randomly where the experimental class obtained learning with a problem-solving approach, and the control class gained regular learning. Class VII L as the experimental class and class VII I as the control class. The instrument in this study is a set of test questions in the form of a description consisting of eight questions. Based on the results of research and analysis of pretest, posttest, and n-gain data, it was found that the achievement and improvement of students' creative mathematical thinking skills using problem-solving approaches compared to those using ordinary learning, and implementation of learning steps with problem-solving approaches in the field showed that the learning process is more effective and creative in mathematical problems solving.
\end{abstract}

Copyright $@ 2019$ IKIP Siliwangi. All rights reserved.

\section{Corresponding Author:}

Heris Hendriana,

Departement of Mathematics Education,

Institut Keguruan dan Ilmu Pendidikan Siliwangi,

Jl. Terusan Jenderal Sudirman, Cimahi, West Java 40526, Indonesia

Email: herishen@ikipsiliwangi.ac.id

\section{How to Cite:}

Hendriana, H., \& Fadhilah, F. M. (2019). The students' mathematical creative thinking ability of junior high school through problem-solving approach. Infinity, 8(1), 11-20.

\section{INTRODUCTION}

The ability to think creatively is an ability that is important for students to have so that students can solve problems faced in learning activities (Istianah, 2013). In the learning process, especially in mathematics learning, the ability to think mathematically has a very important role to do and needs to be applied to students (Choridah, 2013; Darusman, 2014; Istianah, 2013; Nuriadin, 2015; Rahman, 2012; Sugilar, 2013; Yenni \& 
Putri, 2017). In learning mathematics in schools students should be trained to have creative thinking skills in obtaining, choosing, and processing information in order to survive in an ever-changing and competitive situation (Darusman, 2014).

Mathematical creative thinking ability of students at the junior high school level is still very low, this is because when students are given students do not want to work on the problem even students give up first before trying to solve the problem (Rahman, 2012; Sugilar, 2013). In addition, based on the research results of Hidayat (2017), it was found that students' thinking abilities had not been achieved in the category of novelty indicators. This is difficult, because students still think the transition from concrete to abstract. So that when students are required to think creatively in a given problem, the solution is still following the usual algorithmic processes solved for routine problems (Hidayat, Wahyudin \& Sufyani, 2018).

Facts the show that students are less motivated to learn, students' attention to learning outcomes or values obtained by students seem to accept what they are and "resign" even when they get a score below the completeness criteria even if the student does not want to make improvements (Sumarmo, Hidayat, Zukarnaen, Hamidah, \& Sariningsih, 2012). So that the ability of mathematical creative thinking of Junior High School students is still low. This can be seen from the value of the seventh grade daily math test of SMP Negeri 1 Cilamaya Wetan consisting of 32 students, 22 students of whom still have difficulties in solving problems in the form of high-level thinking questions that involve various concepts and only 9 other students who can solve the problem. Thus, only $28 \%$ of students from 32 students were able to solve the problem.

The main factor of the low ability of mathematical creative thinking of students is influenced by the learning approach used by the teacher. The teacher conveys the material and provides sample questions without involving student interaction on opinions and analysis, so that students think according to what is conveyed by the teacher, students' creative thinking skills are less developed. Therefore it is necessary to develop a learning approach that involves students more actively and able to think creatively in the teaching and learning process and in accordance with mathematics learning (Istianah, 2013; Yenni $\&$ Putri, 2017). One approach to learning mathematics that can be applied in anticipating problems that arise during the learning process of mathematics and can generate creative ideas is a problem solving approach. With the problem solving approach is expected to be able to attract the attention and interest of students in following the process of learning mathematics.

\section{METHOD}

The method in this study is a quasi-experimental method, because there is a treatment manipulation, where the experimental class uses learning with a problem solving approach, and the control class uses ordinary learning. Before getting treatment first, both classes are given an initial test (pretest) and after receiving treatment, the two classes are given a final test (post test). The designs in the study are as follows:

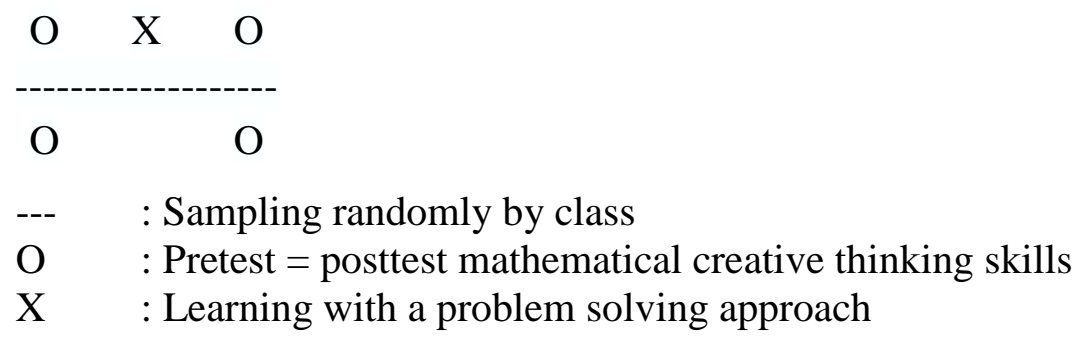


The population in this study were all students of SMP Negeri 1 Cilamaya Wetan. With the sample subjects are two class VII, while the sample is selected 2 classes randomly where the experimental class obtains learning with a problem solving approach, and the control class receives ordinary learning. Class VII L as an experimental class and class VII I as a control class.

Examples of junior high school creative thinking ability test questions:

A frame model of a beam is made of wire with a length $(x+5) \mathrm{cm}$, width $x$ $\mathrm{cm}$, and height $(x-2) \mathrm{cm}$. If the length of the wire used is not more than $132 \mathrm{~cm}$, determine the steps to determine the maximum size of the beam!

The results of both pretest and posttest research were processed using SPSS 21.0 for Windows software with the following steps:

a. Test the normality of the results data pretest with the aim to find out whether the sample comes from a population that is normally distributed. The normal assumption on the distribution of data to be analyzed is one of the requirements in quantitative analysis. The normality test used using the Kolmogorov-Smirnov normality test with a significance level of 0.05 .

b. If the two classes are normally distributed, then the homogeneity test is done to find out both the distribution of the experimental class and the control class whether the variances are the same or not. The homogeneity test used using the Levene Statistics test.

c. If one or both classes are not normally distributed, followed by a two-mean similarity test using non-parametric test statistics.

d. If the two classes are normally distributed and homogeneous, then the two-mean similarity test is continued using the t-test.

e. If the two classes are normally distributed but not homogeneous, then the two similarity test uses the t-test.

f. The two mean similarity test on pretest data used a two-party test. While the two mean similarity tests on posttest and n-gain data use the one-party test. The similarity test of the mean pretest score aims to find out that there is no significant difference in the initial ability of the experimental group and the control group. While the two mean similarity test in the posttest and n-gain to find out the achievement and improvement of mathematical creative thinking abilities of students who learn using problem solving approaches is better than those using ordinary learning.

\section{RESULTS AND DISCUSSION}

\subsection{Results}

In the data analysis the results of mathematical creative thinking skills between students who use problem solving approaches with those using ordinary learning, the data obtained are data of mathematical creative thinking abilities obtained from the results of pretest and posttest. From the results of these two tests, another quantitative data is obtained, namely the data gain of students' mathematical creative thinking ability. Data processing is done using SPSS 21.0 for Windows software.

Before being analyzed, it will be presented first descriptive of the ability score of the pretest, posttest, and $\mathrm{N}$ - Gain in the following table. 
Table 1. Description of Research Results

\begin{tabular}{ccccccccc}
\hline \multirow{2}{*}{ Approach } & \multicolumn{3}{c}{ Pretest } & \multicolumn{3}{c}{ Postest } & \multicolumn{2}{c}{ N-Gain } \\
\cline { 2 - 9 } & $\overline{\mathbf{x}}$ & SD & SMI & $\overline{\mathbf{x}}$ & SD & SMI & $\overline{\mathbf{x}}$ & SD \\
\hline Problem solving & 8.82 & 1.688 & 32 & 23.32 & 2.504 & 32 & 0.6273 & 0.0972 \\
conventional learning & 8.20 & 1.862 & 32 & 21.16 & 2.292 & 32 & 0.5457 & 0.8081 \\
\hline
\end{tabular}

Based on Table 1 above, it can be concluded that the initial ability of mathematical creative thinking in both classes is not much different. After learning, the ability of experimental class mathematical creative thinking is better than control class means increasing the ability to think mathematically creative using a problem solving approach better than those using ordinary learning.

In the analysis of the initial test data (pretest), after the normality test was obtained, the data was normally distributed, then continued with a variance homogeneity test. The results of homogeneity variance test obtained homogeneous data. Furthermore, the two average difference test was carried out using SPSS 21.0 for Windows software, so the following results were obtained:

Table 2. Significant Test Results of the Difference in Two Average Pretest Scores

\begin{tabular}{|c|c|c|c|c|}
\hline \multirow{2}{*}{ Approach } & \multirow{2}{*}{ SD } & \multicolumn{2}{|c|}{ T-test } & \multirow{2}{*}{ Interpretation } \\
\hline & & $\mathbf{T}_{\text {count }}$ & Sig. & \\
\hline Problem Solving & 1.688 & $1<r_{0}$ & 0 & \\
\hline conventional learning & 1.862 & 1.019 & 0.109 & $\Pi_{0}$ ace epted \\
\hline
\end{tabular}

Based on the results in Table 2 it can be seen that the significant value of sig. (2tailed) with the t-test is 0.600. Because the value of $\mathrm{Sig}>0.05, \mathrm{H} 0$ is accepted with a significant level of $5 \%$. Thus it can be concluded that the ability of students to think mathematically creative in the initial test there is no significant difference between those who will use problem solving learning with those who will use ordinary learning.

Analysis of the final test data was conducted to determine the improvement of students' creative thinking skills after the approach process and to determine the equality of the sample.

Both data are assumed to be normal and homogeneous with a significant level of $5 \%$. Furthermore, a significant test of the two average differences was carried out using the one-t-test of the right party using the Independent Sample T-Test assuming both homogeneous variance (equal variance assumed) with a significance level of 0.05 . In this case the researcher uses the right-hand test with the aim of knowing which learning is better.

Table 3. Significant Test Results for the Difference in Two Average Postes Scores

\begin{tabular}{ccccc}
\hline \multirow{2}{*}{ Approach } & SD & \multicolumn{2}{c}{ T-test } & \multirow{2}{*}{ Interpretation } \\
\cline { 3 - 4 } & & $\mathbf{T}_{\text {count }}$ & Sig. & \\
\hline Problem Solving & 2.504 & \multirow{2}{*}{4.219} & 0.000 & $\mathrm{H}_{0}$ rejected \\
conventional learning & 2.292 & & & \\
\hline
\end{tabular}


Based on the results in Table 3 it can be seen that the significant value of sig. (2tailed) with the t-test is 0.000 . Because the value of Sig. (2-tailed) $<0.05$, H0 is rejected. So it can be concluded that the achievement of mathematical creative thinking abilities of students who use a problem solving approach is better than those who use ordinary learning.

$\mathrm{N}$-Gain data analysis was conducted to determine the improvement of mathematical creative thinking skills between those who used problem solving approaches with those who used ordinary learning.

In the n-gain data analysis, both data are assumed to be normal and homogeneous with a significant level of 5\%. Furthermore, a significant test of the two average differences was carried out using the one-t-test of the right party using the Independent Sample T-Test assuming both homogeneous variance (equal variance assumed) with a significance level of 0.05 .

Table 4. Significant Test Results for the Difference in the Two Average N-Gain Indexes

\begin{tabular}{|c|c|c|c|c|}
\hline \multirow{2}{*}{ Approach } & \multirow{2}{*}{ SD } & \multicolumn{2}{|c|}{ T-test } & \multirow{2}{*}{ Interpretation } \\
\hline & & $\mathbf{T}_{\text {count }}$ & Sig. & \\
\hline Problem Solving & 0.972 & \multirow{2}{*}{4.284} & \multirow{2}{*}{0.000} & \multirow{2}{*}{$\mathrm{H}_{0}$ rejected } \\
\hline conventional learning & 0.808 & & & \\
\hline
\end{tabular}

Based on the results in Table 4 it can be seen that the significant value of sig. (2tailed) with the t-test $<0.05$ then $\mathrm{HO}$ is rejected. Thus it can be concluded that the increase in mathematical creative thinking skills of students who learn using a problem solving approach is better than those who use ordinary learning.

\subsection{Discussion}

Learning activities carried out as many as 10 meetings with different learning (treatment), namely the experimental class using the problem solving approach and the control class using the usual learning approach. Learning is done 8 times, 1 meeting for pretest, and 1 more meeting for postes.

After the post-test, the data shows that the sample comes from a population that is normally distributed, the variance of the two sample groups is homogeneous, there are differences in the ability of creative mathematical thinking between the experimental class and the control class on the significance test of the two mean differences. It can be concluded that in the final test (posttest) the achievement of mathematical creative thinking abilities of students who use a problem solving approach is better than those who use ordinary learning.

In the experimental class given learning using a problem solving approach. At the second meeting until the meeting of the seven students in the experimental class was grouped, students were given material and practice questions in the form of worksheets, students discussed with friends in a group doing the exercises on LKS, then students had to present the results of the discussions they were working on.

At the first meeting students in several groups were seen discussing with friends in the group, some students asked questions and gave opinions in solving problems, in addition students were more enthusiastic in issuing their opinions even though these opinions did not lead to problem solving, but some students still had feeling confused. This 
is because at the initial meeting, the majority of students were still in the form of adjustments to the learning provided. The difficulties faced by students are not solved in the form of comprehensive discussions. The results of the study by Dilla, Hidayat \& Rohaeti (2018) found that when students find it difficult to solve problems, they will guess the possible solutions. From this process, students actually have creative thinking skills. At the next meeting, some students begin to actively argue and ask questions, opinions and questions begin to lead to problem solving.

Learning that uses a problem solving approach shows a significant role in improving students' creative thinking skills. In learning that uses a problem solving approach, the focus of learning activities is entirely on students, namely thinking creatively in understanding a problem, planning the completion of a mathematical problem, solving problems and checking all the steps that have been done. Because problem solving learning can challenge students' abilities and provide satisfaction to find new knowledge for students and can help students to develop new knowledge and be responsible for the learning they do. In addition, solving the problem can also encourage self-evaluation of both the results and the learning process. This is one of the advantages of problem solving that shows that the experimental class is better than the control class.

During the research process there are several obstacles that arise, including constraints with time. In the learning process that uses a problem solving approach requires additional time as its application, because in the learning process students must understand the problems contained in the worksheet and students must plan the resolution of the problem. Therefore, the learning process that uses a problem solving approach requires a little more time than ordinary learning (Jonassen, \& Hung, 2015; Karatas, \& Baki, 2017; Loibl, Roll, \& Rummel, 2017; Özsoy, \& Ataman, 2017; Riccomini, Smith, Hughes, \& Fries, 2015).

In the control class, ordinary learning is given. During the second meeting until the seventh meeting students were given regular learning. The teacher only provides material and students only listen and get material in one direction. Students are seen busy with each material provided by the teacher. In the ordinary learning process students become more passive, most students hesitate in solving problems in the form of problems, most students look saturated. Students look familiar with activities that tend to be monotonous and boring. Thus students will be difficult in capturing material, in the end students have no interest in following these subjects. So that the ordinary learning approach is not effective in developing the creativity of each student.

It can be understood that ordinary learning is only oriented to explaining the subject matter, explaining the steps in solving the problem and providing examples of problem solving in a clear and detailed way and then students are asked to work on the questions that have been presented clearly and the problem solving is definitely uniform. In addition, students are not given the opportunity to express and conclude the material they have learned in their own language. This makes mathematics only seen as a set of formulas and rules that must be memorized and remembered by students not as activities or activities that must be done by students to find a concept (Godino, Batanero, \& Font, 2007; Hendriana, 2017; Kaiser, \& Sriraman, 2006; Surya, Sabandar, Kusumah, \& Darhim, 2013; Widyatiningtyas, Kusumah, Sumarmo, \& Sabandar, 2015; Zan, Brown, Evans, \& Hannula, 2006).

In the calculation of the gain of the experimental class and the gain of the control class that the sample comes from a population that is normally distributed, and the gain results have homogeneous variance and there is an increase in mathematical creative thinking skills students who use a problem solving approach better than those who use ordinary learning in the significance test difference of two averages. 
Based on the data processing above, shows that the achievement and improvement of mathematical creative thinking abilities of students who are learning using a problem solving approach is better than those using ordinary learning, and the implementation of learning steps by using a problem solving approach in the field. This result is in line with opinions Sumarmo, Hidayat, Zukarnaen, Hamidah, \& Sariningsih (2012) stated that the implementation of mathematics learning using a problem solving approach can improve students' creative thinking ability in learning mathematics. Based on observations of researchers in the field, it shows that:

a. Students can understand the problem,

b. Planning completion.

c. Resolve the problem.

d. Re-checking all steps that have been done

Based on the observations of researchers in the field, problem solving approaches are better than those who use ordinary learning approaches. The observations of researchers in the field are in line with Sumarmo, Hidayat, Zukarnaen, Hamidah, \& Sariningsih (2012) opinion, this is caused by:

a. Students play an active role in learning

b. Improving ability to work together.

c. With problem solving learning, students better understand the contents of the lesson.

d. Problem solving learning can challenge students' abilities and provide satisfaction to find new knowledge for students.

e. Problem solving learning can increase student learning activities.

f. Problem solving learning can help students to develop their new knowledge and be responsible for the learning they do. In addition, solving the problem can also encourage self-evaluation of both the results and the learning process.

g. Problem solving learning is considered more enjoyable and liked by students.

\section{CONCLUSION}

Based on the results of research and data analysis, it can be concluded that: (1) The achievement of mathematical creative thinking abilities of students who learn using a problem solving approach is better than those who use ordinary learning; (2) Improvement of mathematical creative thinking skills of students whose learning uses a problem solving approach better than those who use ordinary learning; (3) The implementation of the learning steps using the problem solving approach in the field shows that the learning process is going well and students are more creative in solving mathematical problems.

\section{REFERENCES}

Choridah, D. T. (2013). Peran Pembelajaran Berbasis Masalah Untuk Meningkatkan Kemampuan Komunikasi Dan Berpikir Kreatif Serta Disposisi Matematis Siswa SMA. Infinity Journal, 2(2), 194-202.

Darusman, R. (2014). Penerapan Metode Mind Mapping (Peta Pikiran) untuk Meningkatkan Kemampuan Berpikir Kreatif Matematik Siswa SMP. Infinity Journal, 3(2), 164-173.

Dilla, S. C., Hidayat, W., \& Rohaeti, E. E. (2018). Faktor Gender dan Resiliensi dalam Pencapaian Kemampuan Berpikir Kreatif Matematis Siswa SMA. Journal of 
Medives: Journal of Mathematics Education IKIP Veteran Semarang, 2(1), 129136.

Godino, J. D., Batanero, C., \& Font, V. (2007). The onto-semiotic approach to research in mathematics education. ZDM, 39(1-2), 127-135.

Hendriana, H. (2017). Teachers' hard and soft skills in innovative teaching of mathematics. World Trans. Eng. Technol. Educ, 15, 145-50.

Hidayat, W. (2017). Adversity Quotient dan Penalaran Kreatif Matematis Siswa SMA dalam Pembelajaran Argument Driven Inquiry pada Materi Turunan Fungsi. KALAMATIKA Jurnal Pendidikan Matematika, 2(1), 15-28.

Hidayat, W., Wahyudin, W., \& Prabawanto, S.(2018). Improving students' creative mathematical reasoning ability students through adversity quotient and argument driven inquiry learning. In Journal of Physics: Conference Series, 948(1).

Istianah, E. (2013). Meningkatkan Kemampuan Berpikir Kritis dan Kreatif Matematik dengan Pendekatan Model Eliciting Activities (MEAs) pada Siswa SMA. Infinity Journal, 2(1), 43-54. https://doi.org/https://doi.org/10.22460/infinity.v2i1.23

Jonassen, D. H., \& Hung, W. (2015). All problems are not equal: Implications for problem-based learning. Essential Readings in Problem-Based Learning, 7-41.

Kaiser, G., \& Sriraman, B. (2006). A global survey of international perspectives on modelling in mathematics education. $Z d m, 38(3), 302-310$.

Karatas, I., \& Baki, A. (2017). The effect of learning environments based on problem solving on students' achievements of problem solving. International Electronic Journal of Elementary Education, 5(3), 249-268.

Loibl, K., Roll, I., \& Rummel, N. (2017). Towards a theory of when and how problem solving followed by instruction supports learning. Educational Psychology Review, 29(4), 693-715.

Nuriadin, I. (2015). Pembelajaran Kontekstual Berbantuan Program Geometer's Sketchpad dalam Meningkatkan Kemampuan Koneksi dan Komunikasi Matematis Siswa SMP. Infinity Journal, 4(2), 168-181.

Özsoy, G., \& Ataman, A. (2017). The effect of metacognitive strategy training on mathematical problem solving achievement. International Electronic Journal of Elementary Education, 1(2), 67-82.

Rahman, R. (2012). Hubungan Antara Self-Concept terhadap Matematika dengan Kemampuan Berpikir Kreatif Matematik Siswa. Infinity Journal, 1(1), 19-30.

Riccomini, P. J., Smith, G. W., Hughes, E. M., \& Fries, K. M. (2015). The language of mathematics: The importance of teaching and learning mathematical vocabulary. Reading \& Writing Quarterly, 31(3), 235-252.

Sugilar, H. (2013). Meningkatkan Kemampuan Berpikir Kreatif dan Disposisi Matematik Siswa Madrasah Tsanawiyah melalui Pembelajaran Generatif. Infinity Journal, 2(2), 156-168.

Sumarmo, U., Hidayat, W., Zukarnaen, R., Hamidah, M., \& Sariningsih, R. (2012). Kemampuan dan Disposisi Berpikir Logis, Kritis, dan Kreatif Matematik (Eksperimen terhadap Siswa SMA Menggunakan Pembelajaran Berbasis Masalah dan Strategi Think-Talk-Write). Jurnal Pengajaran MIPA, 17(1), 17-33. 
Surya, E., Sabandar, J., Kusumah, Y. S., \& Darhim, D. (2013). Improving of junior high school visual thinking representation ability in mathematical problem solving by CTL. Journal on Mathematics Education, 4(1), 113-126.

Widyatiningtyas, R., Kusumah, Y. S., Sumarmo, U., \& Sabandar, J. (2015). The impact of problem-based learning approach to senior high school students'mathematics critical thinking ability. Journal on Mathematics Education, 6(2), 107-116.

Yenni, \& Putri, S. E. (2017). Optimalisasi Kemampuan Berpikir Kreatif Matematis Siswa SMP melalui Pembelajaran Everyone is A Teacher Here. JNPM (Jurnal Nasional Pendidikan Matematika), 1(2), 334-348.

Zan, R., Brown, L., Evans, J., \& Hannula, M. S. (2006). Affect in mathematics education: An introduction. Educational studies in mathematics, 63(2), 113-121. 
